\title{
Recent harvest records of commercially valuable precious corals in the Ryukyu Archipelago
}

\author{
Masanori Nonaka ${ }^{1, *}$, Katherine Muzik ${ }^{2}$ \\ ${ }^{1}$ Okinawa Churaumi Aquarium, 424 Ishikawa Motobu-Cho, Okinawa 905-0206, Japan \\ ${ }^{2}$ Japan Underwater Films, 617 Yamazato, Motobu-Cho, Okinawa 905-0219, Japan
}

\begin{abstract}
Data, including depth, temperature and substrate, are reported for 143 colonies of 3 species of precious corals (Subclass Octocorallia; Family Coralliidae) collected in the Ryukyu Archipelago from June 2005 to May 2008. Colonies were collected by a commercial harvesting company using a remotely-operated vehicle (ROV) and a manned submersible, and identified tentatively as Paracorallium japonicum, Corallium elatius and Corallium konojoi. The data suggest that these species live deeper in lower latitudes (Amami, Okinawa and Ishigaki regions) than in higher latitudes (southern Kagoshima). Colonies of $C$. elatius may be larger at lower latitudes than at higher latitudes, but with the data available so far this cannot be definitely determined. Size differences may reflect harvest history, not physical or biological factors. (The more southern regions have been exploited more recently than the northern region.) There has not yet been enough data made available to estimate the resource of precious corals remaining in the Ryukyu Archipelago. More studies of their taxonomy and biology, especially growth rates, age and size at fertility and timing of reproduction, and data on biomass are necessary in order to make meaningful estimates.
\end{abstract}

KEY WORDS: Precious corals · Coralliidae - Commercial harvest records · Ryukyu Archipelago · Submersible/ROV harvest

\section{INTRODUCTION}

Species in the genera Corallium and Paracorallium (Subclass Octocorallia; Order Alcyonacea; Family Coralliidae) have long been known as precious corals because of the use of their skeletons for ornament, medicine and other valuable products. For many thousands of years, precious corals have been collected from the Mediterranean and have attracted the interest of mankind worldwide (Grigg 1975). In Japan, the precious coral fishery began in Kochi during the 19th century (Kosuge 1993), and continues to the present day in the areas of Kochi, Kagoshima and the Ryukyu Archipelago. It is generally believed that the biomass of precious corals has decreased because of collecting, but until now, no data from commercial harvesting have been published. There is not yet enough data available to estimate the abundance of precious corals remaining. Our goal here is to begin addressing this deficit by reporting recent data provided to us by a local harvesting company. We undertake this work to begin efforts for management and conservation of the precious coral resource.

The first mention in the scientific literature of a Japanese precious coral was by Ridley $(1882$, p. 229), who described a colony 'said to come from Japan' and which he tentatively identified as Pleurocorallium secundum var. elatior. Kishinouye made the first studies in Japan of Japanese precious corals (Kishinouye 1902, 1903a,b, 1904a,b), investigating aspects of their anatomy, chemistry, morphology, reproduction, symbioses and taxonomy. His work is the only taxonomic work ever undertaken on the group since Ridley's first mention. He gave species rank to Ridley's variety, naming it Corallium elatius, and named 6 new species from Japanese waters, C. boshuensis, C. japonicum, C. inutile, C. konojoi, C. pusillum and C. sulcatum. Over 50 yr later, Bayer (1956) described new species of 
Corallium from Hawaiian waters, and provided in the same publication a taxonomic key to all species known at the time, including thoses from Japan.

According to Grigg (1975), colonies tentatively identified as Corallium elatius and C. konojoi were seized from a Japanese fishing boat off the coast of Palau in 1973. Pasternak (1981) recorded C. boshuensis in the Marcus-Necker Sea Mounts near Hawaii. Grigg (1984) reported the distribution by latitude and depth of 3 commercial species in Japan, including: C. japonicum from mainland Japan, Okinawa, and the Bonin Islands and C. konojoi and C. elatius from Japan to the Philippines. (The Japanese species known as C. japonicum is now known as a species of Paracorallium, being moved to this new genus by Bayer \& Cairns in 2003.) Harper (1988) reported on the distribution of precious corals in the South Pacific region, listing $C$. konojoi and $C$. elatius from the Solomon Islands, Paracorallium inutile from Tonga and P. japonicum from Vanuatu. Imahara (1996) listed all octocorals ever described from Japanese waters, including species of Corallium. With the exception of Kishinouye's work over 100 yr ago, most of these reports on Japanese precious corals were very brief, with identifications often tentative.

Studies of the biology and ecology of Japanese precious corals remain scarce. Basic information of their natural history, such as how much these corals grow on an annual basis, age at reproduction and even time of spawning, are not yet known. There is just one report (Grigg 1974) giving growth rates of Japanese corals. In a personal communication to Grigg from U. Kurata, growth rates of up to $0.3 \mathrm{~cm} \mathrm{yr}^{-1}$ in length were reported for tagged specimens of Paracorallium japonicum. Recent studies in Japan (Ueno et al. 1993, Ueno \& Tashima 1998, Iwase 1995, Nonaka et al. 2006, Reimer et al. 2008) have focused only on the biology of Japanese precious corals in captivity.

\section{MATERIALS AND METHODS}

Sampling. Colonies were collected from the Ryukyu Archipelago, the southernmost region of Japan (Fig. 1). In the northern (southern Kagoshima) and Amami regions of the Ryukyu Archipelago, corals were collected by manned submersible at depths of 115 to $300 \mathrm{~m}$ (Appendix 1). In the southern regions (Okinawa and Ishigaki), corals were collected by remotely operated vehicle
(ROV) from depths of 194 to $319 \mathrm{~m}$ (Appendix 1). The samples were selectively harvested for commercial use, with larger colonies more likely to be collected and colonies under certain sizes avoided. Data (water depth, temperature, type of substratum and latitude) were recorded for the immediate area of the sample collected. From 4 June 2005 to 1 March 2006, we obtained 83 samples, and from 23 June 2007 to 27 May 2008, an additional 60 samples (Appendix 1). To protect the resource, and to keep the agreement made with the harvesting company for this research, only approximate latitudes and no longitudes of the collecting locations are revealed in this report. It was also agreed not to report specifications of the ROV and submersible used for collection. Photographs were first made of colonies in situ (Fig. 2A); once collected, colonies were photographed with a scale, on-board ship (Fig. 2B). In situ photographs were approximately 300000 pixels $(640 \times 480)$ and on-board photographs were 8 million $(3264 \times 2448)$ pixels. Photographs taken by observers inside the submersible and on-board the submersible support vessel were approximately 6 million pixels $(3072 \times 2048)$. Colony height, width and main stem diameters were calculated by the authors from the digital photographs provided to them by the company, using the scales included in the photos

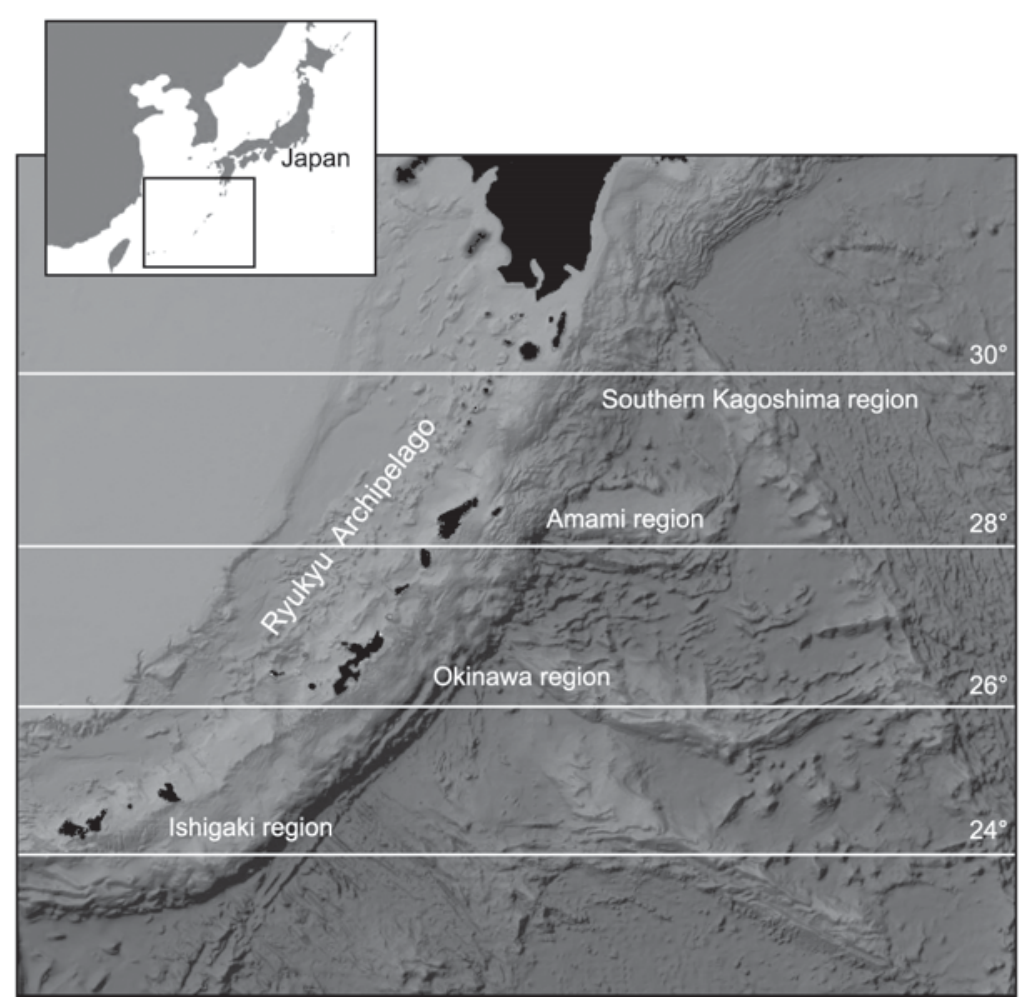

Fig. 1. Regions of collection of Paracorallium japonicum, Corallium elatius and C. konojoi in the Ryukyu Archipelago, Japan, during 2005-2006 and 2007-2008 

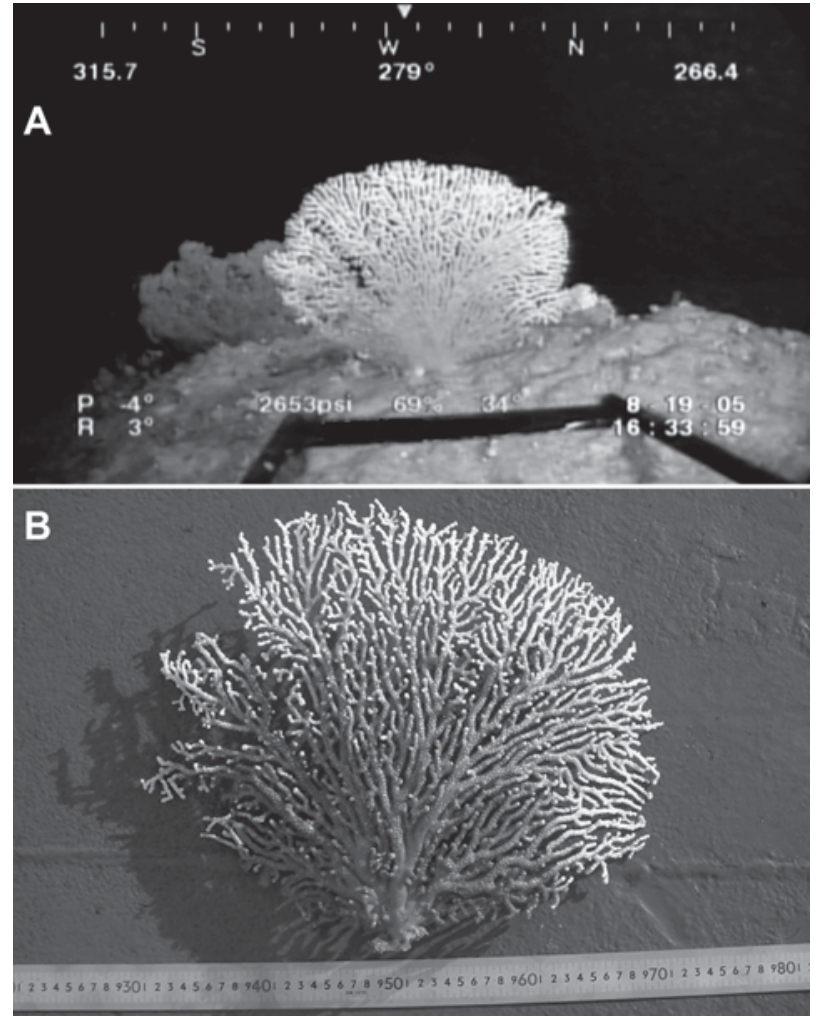

Fig. 2. Corallium elatius. (A) Colony in situ being harvested by ROV. (B) Same colony on-board harvest company vessel, with scale

(Fig. 2B). Colony width is the maximum spread of the colony. Colony height is the maximum height measured perpendicular to the maximum width. Data on densities and biomass were not available. Terminal twigs up to $8 \mathrm{~cm}$ long of each colony sampled were preserved in $99.5 \%$ ethanol and provided by the company to the authors for study $(99.5 \%$ ethanol is recommended for future DNA studies). All samples are being kept in the collection of the Okinawa Churaumi Aquarium.

Identifications. Colonies were identified using accepted morphological characters, such as color, branching pattern, color of axial skeleton and coenenchyme, polyp arrangement, polyp size, and sclerite shape, size and color. Polyp details were observed and measured by light-microscope. Sclerites were separated from the soft tissue of the coenenchyme by treatment with $5 \%$ hypochlorite (ordinary household bleach) and rinsed with tapwater to prepare for scanning electron photographs. Sizes and shapes of sclerites were examined and recorded by using a scanning electronic microscope model Keyence VE-8800. Identifications follow Kishinouye (1903a, 1904a), Bayer (1956), Bayer \& Cairns (2003) and Nonaka \& Muzik (in press). In Japan, there are 7 species recognized in the Family Coralliidae, 6 described by Kishinouye (Kishinouye 1902, 1903a, 1904a,b) and one species by Ridley (1882). For the present study, only the 3 species which have commercial value, Paracorallium japonicum (Kishinouye, 1903), Corallium elatius (Ridley, 1882), and Corallium konojoi Kishinouye, 1903, were examined.

Analysis of biological and environmental data. We examined the following relationships for each species: (1) width frequencies; (2) distribution and colony width; (3) colony width and colony height; (4) colony width and main stem diameter; and (5) depth and latitude of collection site. Broken colonies were excluded from analyses requiring colony measurements. Statistical analysis was performed using Statistica. Water temperature data were collected with each sample and are reported in Appendix 1. Water temperatures for ROV-sampled colonies were taken with a quartz temperature sensor and for submersible-sampled colonies with a mixed-liquid thermometer. Reports from both sensors were accurate to $1^{\circ} \mathrm{C}$.

\section{RESULTS}

\section{Species sampled}

Samples were collected from approximately 100 to $300 \mathrm{~m}$ deep offshore the islands of Ishigaki, Okinawa and Amami, and the small islands offshore southern Kagoshima (Fig. 1, Appendix 1). All colonies reportedly inhabited hard rock substratum. Of the 165 colonies collected, 143 were commercially valuable species and are discussed here. Seventy-eight colonies appeared to be Paracorallium japonicum, 46 Corallium elatius and 19 C. konojoi. Colonies of C. konojoi were found mostly in northern areas, but the other 2 species were present throughout the study area.

\section{Width frequencies}

Width frequencies are shown in Fig. 3. Colonies of Paracorallium japonicum were the smallest of the species sampled. Average $( \pm \mathrm{SD})$ colony width was $37.9 \pm$ $10.48 \mathrm{~cm}$, with a mode ranging from 35 to $40 \mathrm{~cm}$ wide, a maximum colony width of $64 \mathrm{~cm}$ and a minimum width of $18 \mathrm{~cm}$. For Corallium konojoi, the average colony width was $39.4 \pm 12.11 \mathrm{~cm}$, with a mode ranging from 40 to $45 \mathrm{~cm}$, a maximum colony width of $55 \mathrm{~cm}$, and a minimum width of $16.5 \mathrm{~cm}$. The largest colonies were of C. elatius, with an average colony width of 64.2 $\pm 27.76 \mathrm{~cm}$, a maximum width of $157 \mathrm{~cm}$, and a minimum width $25.0 \mathrm{~cm}$, although the mode, 45 to $55 \mathrm{~cm}$, was much smaller. Of all $C$. elatius colonies collected, $35 \%$ were over $75 \mathrm{~cm}$ wide (Fig. 3). Colony widths were significantly different among the 3 species 


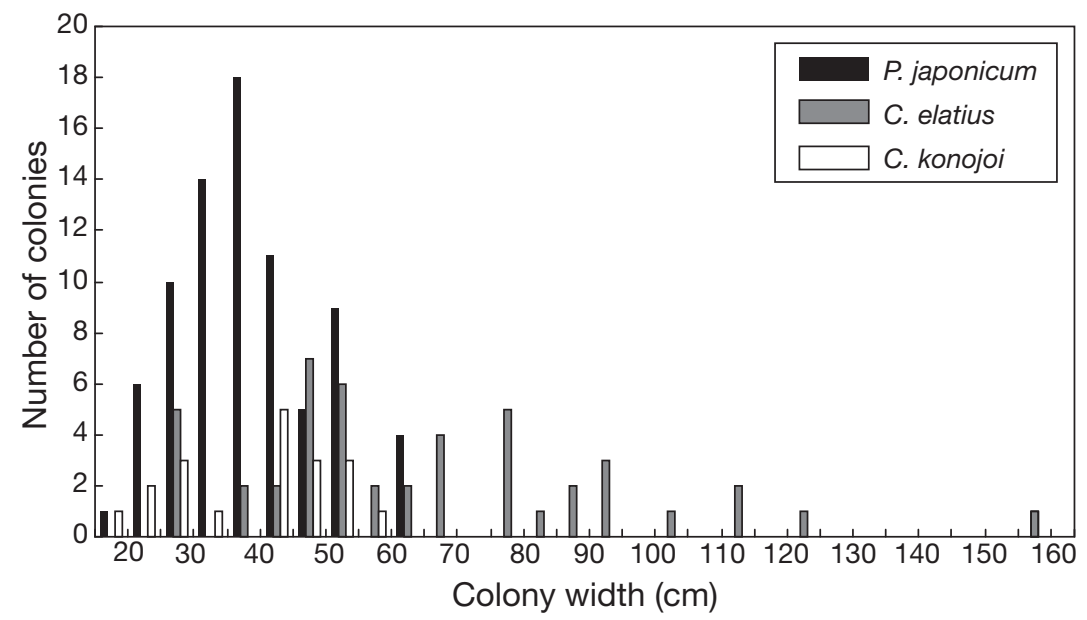

Fig. 3. Paracorallium japonicum, Corallium elatius and C. konojoi. Width frequency distribution of collected colonies

(ANOVA, $\mathrm{p}<0.01$ ). Colonies of $C$. elatius were significantly wider than the other 2 species (Tukey's HSD test, $\mathrm{p}<0.01)$.

\section{Relationships between distribution and colony width}

We collected more colonies of Paracorallium japonicum from near Okinawa than from the northern (southern Kagoshima) and southern regions (near Ishigaki) (Fig. 4), but found no relationship between distribution and colony width in our samples (Fig. 5). We found comparatively wider colonies of Corallium elatius in southern regions, although the largest colony (157 cm wide) was collected from the northern region (Fig. 5). Insufficient samples of C. konojoi were collected to permit drawing any conclusions about distribution by width.

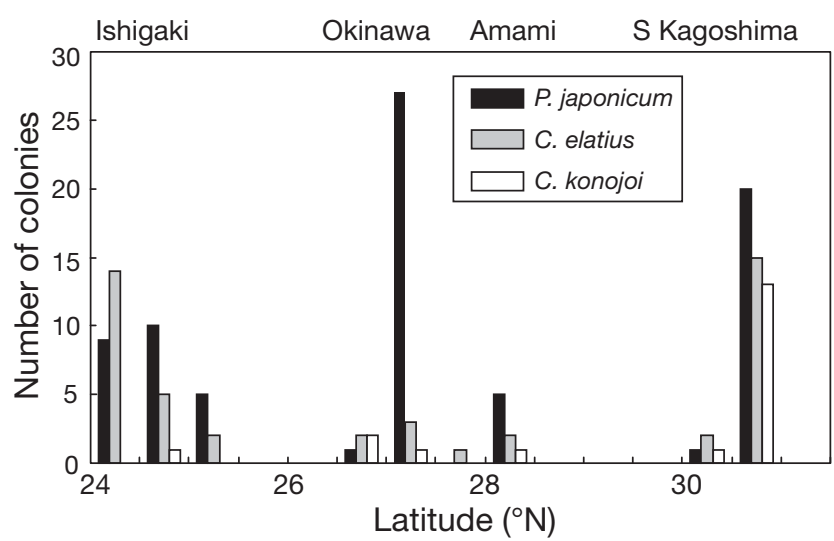

Fig. 4. Paracorallium japonicum, Corallium elatius and C. konojoi. Relationship between latitude and number of colonies for each species sampled during 2005-2006 and 2007-2008

\section{Relationships between (1) colony width and height and (2) colony width and main stem diameter}

Colony width was plotted against colony height for each of the 3 species (Fig. 6A). Of the 143 colonies collected, $86(61 \%)$ were collected intact and were measured to provide this data. Fifty-one specimens were identified as Paracorallium japonicum, 24 as Corallium elatius and 11 as C. konojoi. A significant relationship was found between width and height only for $C$. elatius (Fig. 6A). The correlation analysis for $C$. elatius yielded the equation $y=15.976+0.36205 x$, with $\mathrm{r}^{2}=0.75$. The equations yielded for $P$. japonicum, $y=12.367+0.33073 x\left(\mathrm{r}^{2}=0.51\right) ;$ and for C. konojoi, $y=4.7942+0.56662 x\left(\mathrm{r}^{2}=0.55\right)$, were not significant and the data are not shown.

Colony width was also plotted against diameter of the main stem for each of the 3 species. Again, only for Corallium elatius was there a significant correlation. Correlation analysis yielded the equation $y=36.662+$ $4.1484 x\left(\mathrm{r}^{2}=0.79\right.$; Fig. 6B). In Paracorallium japonicum ( $y$ $\left.=32.649+2.1434 x, \mathrm{r}^{2}=0.35\right)$ and $C$. konojoi $(y=41.379+$ $\left.0.92258 x, r^{2}=0.31\right)$ there appeared to be no correlation between colony width and diameter of the main stem.

\section{Water temperatures at sampling sites}

Temperatures at sampling sites ranged from 14 to $22^{\circ} \mathrm{C}$ and are reported in Fig. 7 and Appendix 1. Differences in temperature at each depth were less than $5^{\circ} \mathrm{C}$ throughout the year in the Ishigaki and Kagoshima

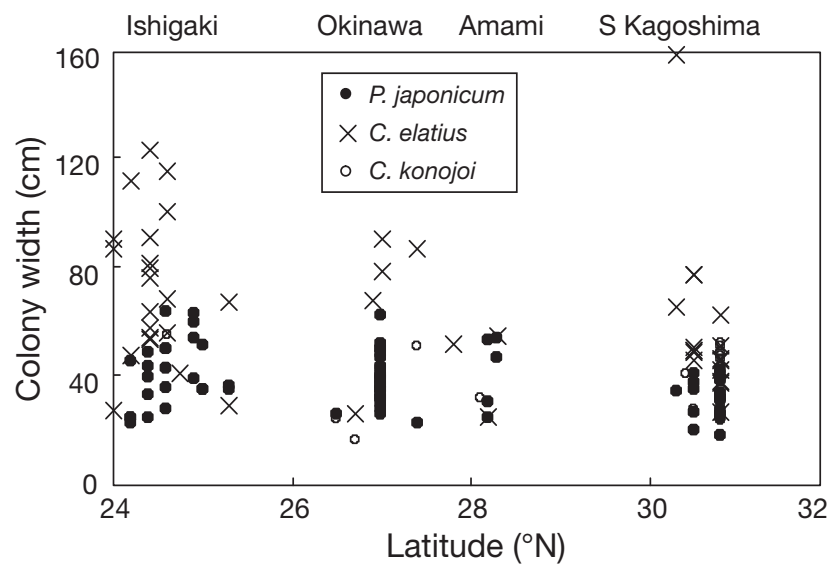

Fig. 5. Paracorallium japonicum, Corallium elatius and C. konojoi. Relationship between latitude and colony width for each species collected 

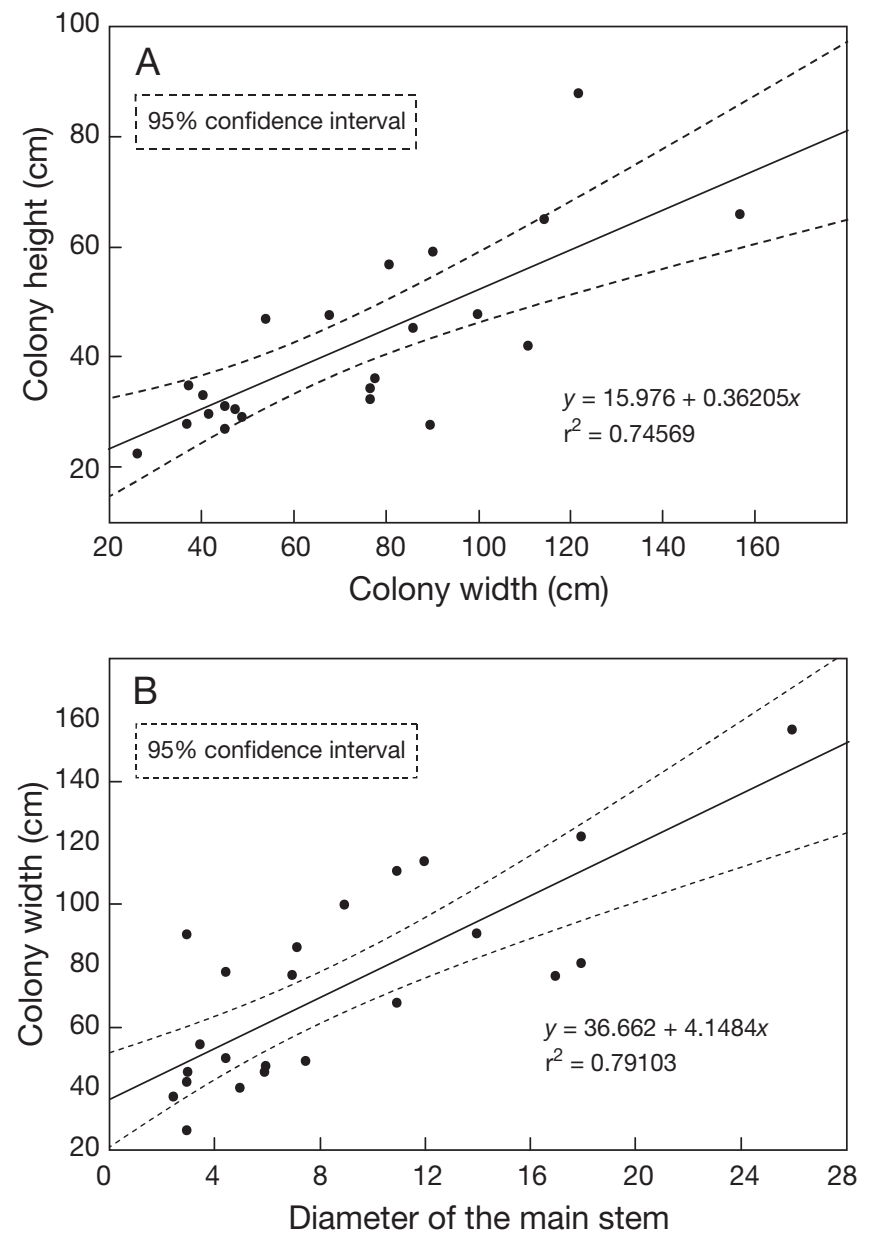

Fig. 6. Corallium elatius. Relationships between (A) colony width and height and (B) main stem diameter and colony width for collected colonies of C. elatius. Each data point represents measurements taken from a photograph of 1 colony. Dotted lines show the $95 \%$ confidence interval of the correlation equation line

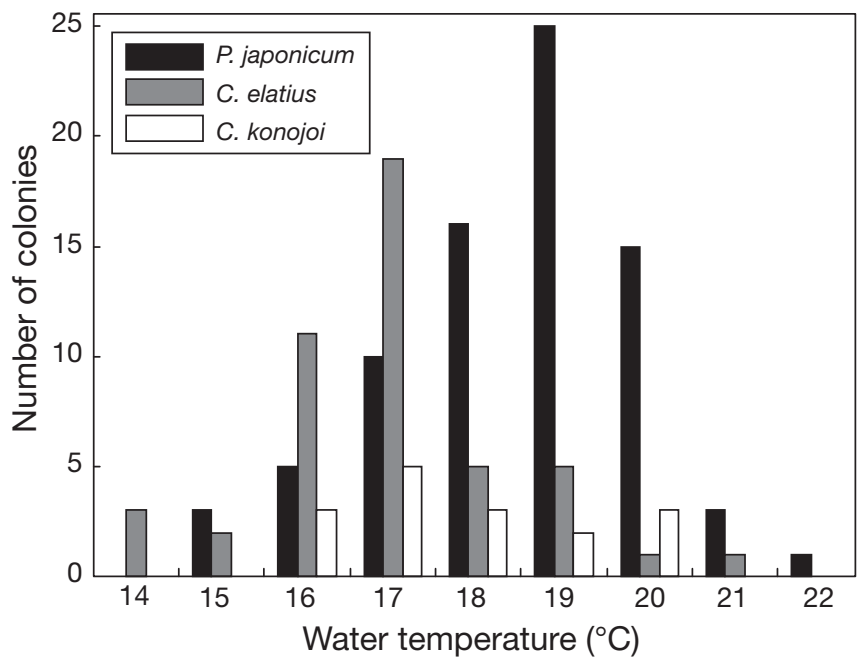

Fig. 7. Water temperatures recorded at time of collection for each species regions (Fig. 8). Only wintertime temperatures were available for the Okinawa region and too few temperatures were available for the Amami region, hence temperature data for those 2 regions are presented only in Appendix 1, not in figures. Lacking complete data for year-round temperatures at these depths and latitudes, no relationships between colony widths and temperatures can yet be inferred (Fig. 9).

\section{Vertical distribution of each species}

Fig. 10 shows collecting depth data arranged in $20 \mathrm{~m}$ increments. All 3 species were collected from nearly the same depth range, 100 to $320 \mathrm{~m}$. Most samples of Paracorallium japonicum were taken from waters less than $261 \mathrm{~m}$ deep, with only one colony from $300 \mathrm{~m}$ deep. For $P$. japonicum, most samples (35 colonies, $45 \%$ ) were taken from the 200 to $220 \mathrm{~m}$ depth range, but 13 samples (17\%) were collected between 120 and $140 \mathrm{~m}$, the shallowest depth range for this species. Colonies of Corallium konojoi were collected from shallower than $255 \mathrm{~m}$, with most colonies collected between 120 and $140 \mathrm{~m}$. The shallowest sample, $115 \mathrm{~m}$ deep, was recorded for this species. Colonies of $C$.

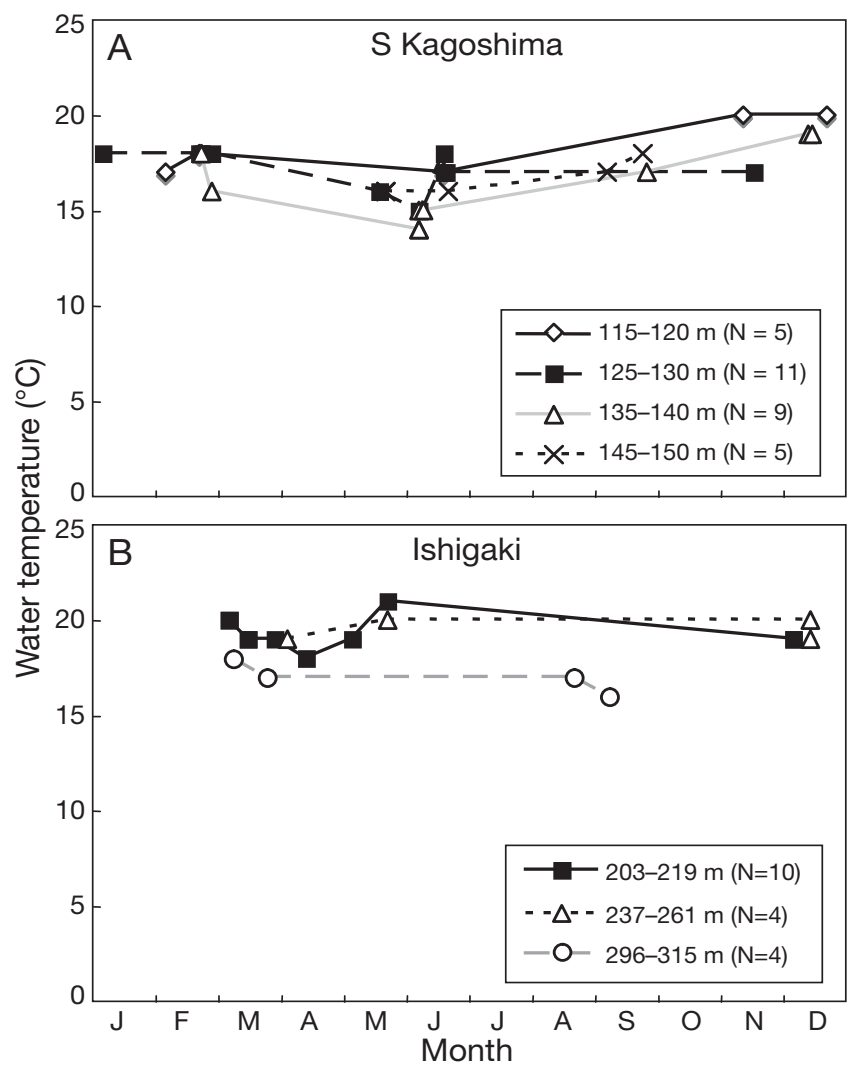

Fig. 8. Harvest station water temperatures by depth range (A) in the southern Kagoshima region, $30.8^{\circ} \mathrm{N}$ and (B) in the Ishigaki region, 24 to $25^{\circ} \mathrm{N}$ 


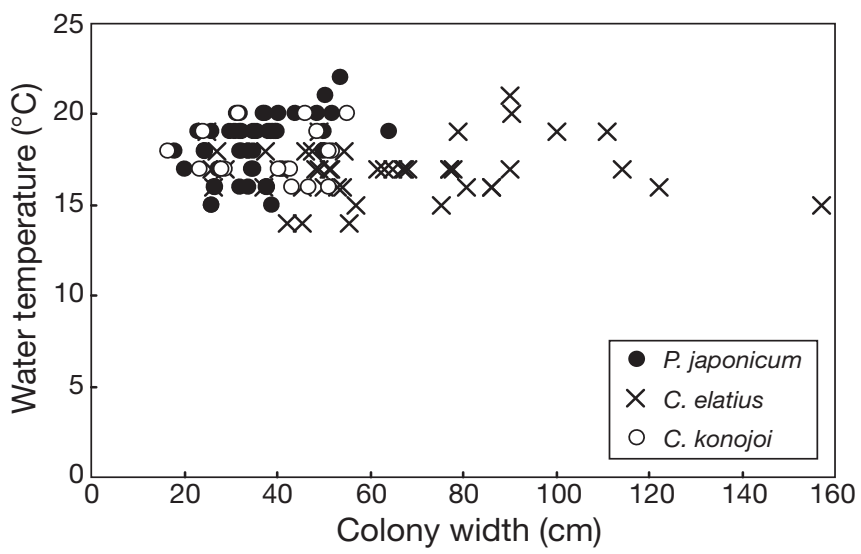

Fig. 9. Paracorallium japonicum, Corallium elatius and $C$. konojoi. Relationship between colony width and water temperature at time and site of collection

elatius were collected from deeper water than the other 2 species, and they were collected evenly from throughout their range. Nine colonies $(19 \%)$ were collected from 200 to 220 m, 8 colonies (17\%) from 280 to $300 \mathrm{~m}$ and 8 from the deepest range, 300 to $320 \mathrm{~m}$.

\section{Relationship between latitude and vertical distribution}

Samples of Paracorallium japonicum were collected from 120 to $300 \mathrm{~m}$ deep. In northern regions they were generally collected from shallower depths (115 to $195 \mathrm{~m}$ ), but in middle and southern regions they were sampled

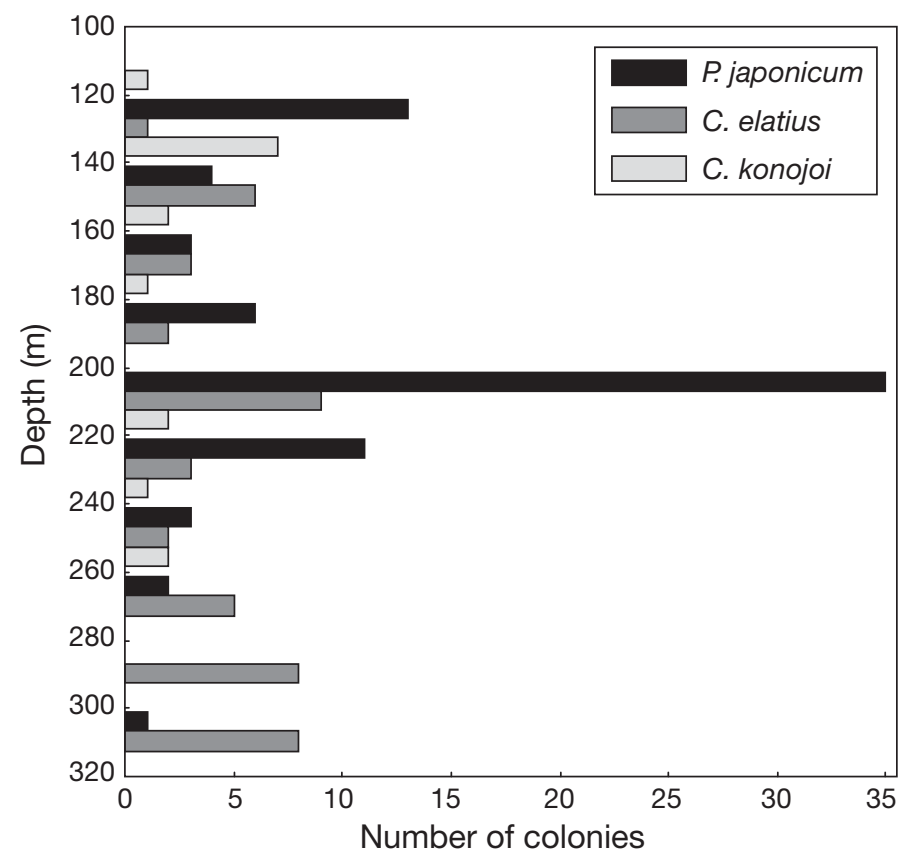

Fig. 10. Paracorallium japonicum, Corallium elatius and $C$. konojoi. Frequency of collection depths for each species, in $20 \mathrm{~m}$ depth bins from deeper depths (194 to $319 \mathrm{~m}$ ). Colonies of Corallium elatius were found in deeper water than the other species. They were collected from 140 to 319 m deep, showing a tendency to inhabit shallower depths in higher latitudes and deeper ones in lower latitudes (Fig. 11).

\section{DISCUSSION}

\section{Identification problems}

The Coralliidae is renowned for difficulty in identification to species level. Their taxonomy has not been studied in Japan since Kishinouye, over 100 yr ago, and the original specimens he described in his publications are unavailable for comparison; apparently, they have been lost. Therefore, our identifications are still tentative. With more collections and more study, it may be found that the Ryukyu corals differ substantially from species in northern Japan, and are new to science. Meanwhile, reliance on just axis color, which has been traditionally used in Japan to sort commercially valuable samples, has sometimes led to taxonomic misidentifications. For example, 5 white coral specimens were classified by manned submersible and ROV crews as belonging to the white coral species known as Corallium konojoi. However, examinations of their sclerites with a microscope showed that 2 specimens were actually a white variety of $C$. elatius, one was Paracorallium inutile and 2 were possibly yet-undescribed species. Relying on axis color only for identification of samples of C. elatius, known as the pink coral, may also result in misidentification. This so-called pink coral has 2 branching morphologies: one with very skinny branches that arise abruptly from a stout trunk, and one with tapering branches arising from a more

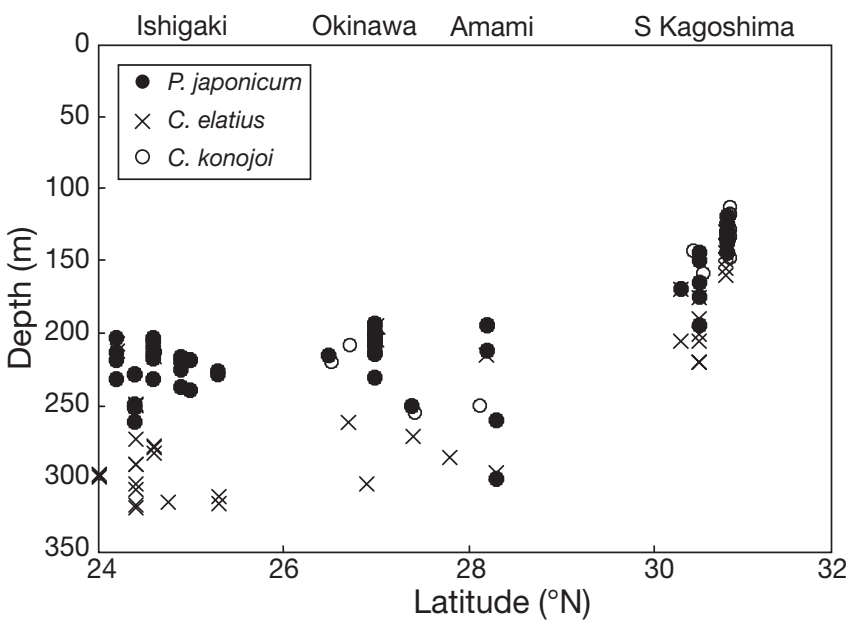

Fig. 11. Paracorallium japonicum, Corallium elatius and $C$. konojoi. Relationship between latitude and depth of collection for each species 
slender trunk. Because branching pattern is often an important character for identification in octocorals, on the basis of their very different branching patterns the 2 morphologies could perhaps be separated into 2 species. However, the shapes and sizes of the sclerites are indistinguishable, so for the present, both morphologies remain classified together. (Data on current and other factors possibly affecting branching pattern are not available.) In summary, several identifications reported in the scientific literature and identifications used by commercial enterprises are doubtful, and those in the present study may be corrected in the future. It is hoped that DNA studies of preserved and new material will help to clarify the situation.

\section{Estimates of colony size}

Because colonies are often broken during harvest, it would be helpful for conservation of the resource to establish an equation for the relationships between colony height and width, and colony width and main stem diameter. For example, if the height is known, the width before breakage can be calculated. Knowing this information would assist conservation efforts by helping to set and enforce collection size limits. Also, when colony shape is an important character for identification, taxonomic studies might be served. Unfortunately, with the data from the present study, only the correlation analysis for Corallium elatius yielded an equation that was significant (Fig. 6). Although many samples of Paracorallium japonicum were measured ( $\mathrm{N}=51)$, there may be too great a variation in the shape of this species to establish a predictable relationship. For $C$. konojoi, sample size $(\mathrm{N}=11)$ may have been too small. The relationships between size and age, and especially age at reproduction, are very important to know in order to guide conservation efforts, but as yet are unknown for any of these species (only large, mature colonies should be allowed to be collected, if any at all). It should be noted that colonies of $P$. japonicum were routinely the smallest of the 3 species collected.

\section{Colony distribution and width}

The maximum colony width recorded for all samples was $157 \mathrm{~cm}$ for a specimen of Corallium elatius (Fig. 3). Kishinouye (1904a) reported large-sized colonies of $C$. elatius (up to $100 \mathrm{~cm}$ tall and wide) and, indeed, our data show that colonies of $C$. elatius were significantly wider than those of Paracorallium japonicum and $C$. konojoi (Fig. 3). Our data also show samples of $C$. elatius tended to be wider at lower latitudes than at higher latitudes (Fig. 5). One explanation for the larger widths sampled at lower latitudes may be historical, not biological. The fishery of precious corals began in Kagoshima in 1902 by dredging (Kitahara 1904), and was quite intense. As a result, the resources may not have recovered yet in that area. Harvest began in Okinawa much later, in 1959 (Kosuge 1987), but without much success. In 1972, research on the coral resources in the northern Ryukyu Archipelago was begun by commercial submersible (Kosuge 1987, Suzuki 1999). Since 1979, collection in the Kagoshima and Okinawa Prefectures has been permitted only by ROV and submersible (Suzuki 1999).

\section{Distribution of Japanese species in Japan and the Pacific}

Three commercially valuable species of Japanese Coralliidae are known to have been collected in southern Japan, Kochi, Kagoshima, the Bonin Islands and the Ryukyu Archipelago (Kosuge 1987, Suzuki 1999), but there are no summary reports of their distribution in Japan. Their northern limit appears to be northern Kyushu, off Nagasaki and Goto Island (Kosuge 1987, Suzuki 1999). The northernmost record in Japan for Corallium is a specimen from Sagami Bay (southwest Tokyo) which may or may not be Paracorallium japonicum (Nonaka \& Muzik in press). Despite several studies, no Japanese Coralliidae have ever been recorded from the Hawaiian or Midway Islands (Bayer 1956, Grigg $1974,1993)$. In the present study in Japan, colonies of $C$. konojoi were found mostly in the southern Kagoshima region (Fig. 4), suggesting that the Ryukyu Archipelago may be the southern limit for this species. The other 2 species, P. japonicum and C. elatius, were present throughout the study area, and therefore it is possible they occur at even more southern latitudes. As mentioned in the 'Introduction', according to Grigg (1975), colonies tentatively identified as C. elatius and C. konojoi were collected in Palau, and in one other unconfirmed report (Harper 1988), colonies of C. elatius, C. konojoi and $P$. japonicum were recorded in the South Pacific region. However, because of the difficulties and problems associated with identification to species level of this group, and without collected material to examine in order to confirm identifications, these records should be viewed with skepticism.

\section{What are the environmental factors of Corallium distribution in the Ryukyu Archipelago?}

This question cannot yet be answered fully because too few environmental variables have been reported. Regarding vertical distribution, the samples were 
found at depths of 115 to $319 \mathrm{~m}$ (Fig. 10, Appendix 1) and so appear to live at shallower depths than do species in Hawaii (Corallium secundum at depths of 350 to $475 \mathrm{~m}$, Grigg 1993). One of the deepest records for Corallium was an undetermined species collected from around Midway at depths of 1000 to 1500 m (Grigg 1993).

Although the depth ranges found in the present study are not yet definitive, the data suggest that these species live deeper at lower latitudes (in the Amami, Okinawa and Ishigaki regions) than in higher latitudes (in the southern Kagoshima region) (Fig. 11). Most colonies of Paracorallium japonicum were collected from depths of 200 to $220 \mathrm{~m}$, and Corallium konojoi were collected from depths of 120 to $140 \mathrm{~m}$ (Fig. 10).

Grigg (1974) commented that Corallium was found in areas of strong bottom currents in the North Pacific basin. Indeed, current is likely to be of extreme importance for determining species distribution of Corallium, as well as many other arborescent species in the Subclass Octocorallia. Currents also likely have an unkown effect on colony shape and size, as illustrated by the 2 morphotypes of what at present are still lumped as pink coral, in the species Corallium elatius.

In summary, the present study is a first step towards determining the precious coral resource in Japan and establishing its proper management and conservation. Information on precious coral distribution, biomass, taxonomy and biology, especially growth rates, age and size at fertility and timing of reproduction are needed in order to determine if there are still sufficient corals remaining to allow their selective harvest, especially of Corallium elatius, in the more southern regions.

Acknowledgements. We thank Dr. N. Iwasaki, Associate Professor of Kochi University, who provided information about precious corals collected from mainland Japan. Y. Imahara, Researcher of Wakayama Laboratory, Biological Institute on Kuroshio, Kuroshio Biological Research Foundation, and F. Iwase, Managing Director of Kuroshio Biological Research Foundation, shared much useful knowledge about Corallium and other octocorals with us. We thank Dr. M. Yamaguchi for providing us literature about precious coral biology and cultural history. E. Neeley of SeaWeb generously shared publications from the SeaWeb coral library with us. We thank the staff of Okinawa Churaumi Aquarium, especially $H$. Yamamoto who gave us advice on data analysis, Y. Kanaya and Dr. S. Kai who helped us analyze the data and A. Shinjo who made measurements from photos for this study. Special thanks to Dr. S. Uchida, director of Okinawa Churaumi Aquarium, for management of this research.

\section{LITERATURE CITED}

Bayer FM (1956) Descriptions and redescriptions of the Hawaiian octocorals collected by the U.S. Fish Commission steamer 'Albatross' (2. Gorgonacea: Scleraxonia). Pac Sci 10:67-95
Bayer FM, Cairns SD (2003) A new genus of the scleraxonian family Coralliidae (Octocorallia: Gorgonacea). Proc Biol Soc Wash 116:222-228

Grigg RW (1974) Distribution and abundance of precious corals in Hawaii. Proc 2nd Int Coral Reef Symp 2:235-340

Grigg RW (1975) The commercial potential of precious corals in the western Caroline Islands, Micronesia. Sea Grant Tech Rep Hawaii Univ UNIHI-SEAGRANT-AR-75-03

Grigg RW (1984) Resource management of precious corals; a review and application to shallow water reef building corals. PSZN I: Mar Ecol 5:57-74

Grigg RW (1993) Precious coral fisheries of Hawaii and the U.S. Pacific Islands: fisheries of Hawaii and U.S.-associated Pacific Islands. Mar Fish Rev 55:50-60

Harper JR (1988) Precious corals prospecting strategies for the South Pacific region. CCOP/SOPAC Technical Report 84

Imahara Y (1996) Previously recorded octocorals from Japan and adjacent seas. Precious Corals Octocoral Res 4-5:17-44

Iwase F (1995) Aka-sango shiiku tenmatsuki. Mar Pavilion 24: 20-21 (in Japanese)

Kishinouye K (1902) Honpou san sango no ichi shinshu. Doubutsu Gaku Zasshi 14:623-626 (in Japanese)

Kishinouye K (1903a) Preliminary note on the Coralliidae of Japan. Zool Anz 26:623-626

Kishinouye K (1903b) Honpou san no sango. Doubutsu Gaku Zasshi 26:623-626 (in Japanese)

Kishinouye K (1904a) Sango no kenkyu. Suisan Chosa Hokoku 14:1-31 (in Japanese)

Kishinouye K (1904b) Notes on the natural history of corals. J Imperial Fish Bureau 14:1-32

Kitahara T (1904) Sango gyogyo chosa hokoku. Suisan Chosa Hokoku 13:1-24 (in Japanese)

Kosuge S (1987) The corals: captivating and charming gifts from Neptune. Special publication No. 2, Institute of Malacology, Tokyo (in Japanese)

Kosuge S (1993) History of the precious coral fisheries in Japan. Precious Corals Octocoral Res 1:30-38

Nonaka M, Muzik K (in press) Jewels of the deep sea: precious corals. In: Uchida S (ed) Into the unknown, researching mysterious deep-sea animals. Proceedings of an International Symposium, 23-24 Feb 2007, Okinawa Churaumi Aquarium, Okinawa

Nonaka M, Muzik K, Uchida S (2006) Capture, study and display of precious corals. Proc 10th Int Coral Reef Symp 5:1821-1831

Pasternak FA (1981) Alcyonacea and Gorgonacea. In: Kuznetsov AP, Mironov AN (eds) Benthos of the sub-marine mountains Marcus-Necker and adjacent Pacific regions. Akademiya Nauk SSSR, Moscow, p 40-55

Reimer JD, Nonaka M, Singer F, Iwase F (2008) Morphological and molecular characterization of a new genus and new species of parazoanthid (Anthozoa: Hexacorallia: Zoantharia) associated with Japanese red coral (Paracorallium japonicum) in southern Japan. Coral Reefs 27:935-949

Ridley SO (1882) On the arrangement of the Coralliidae, with descriptions of new or rare species. Proc Zool Soc Lond 1882:221-233

Suzuki K (1999) SANGO. Cultural history of tools and humanbeings, No. 91. University of Housei Press, Tokyo (in Japanese)

Ueno Y, Tashima K (1998) Culture of precious corals using deep seawater in aquaria. Rep Kochi Deep Seawater Lab 3:35-40 (in Japanese)

Ueno Y, Tashima K, Yamaguchi M, Kashizaki M, Myojin K (1993) Culture of precious corals, Corallium japonicum Kishinouye in aquaria. Precious Corals Octocoral Res 1: $30-38$ 
Appendix 1. Precious coral harvest data in the Ryukyu Archipelago from 2005 to 2008. Is.: Island; Manned sub: manned submersible; ROV: remotely operated vehicle. Substratum was hard rock in all cases

\begin{tabular}{|c|c|c|c|c|c|c|}
\hline $\begin{array}{l}\text { Date } \\
\text { (dd/mm/yy) }\end{array}$ & $\begin{array}{l}\text { Sampling } \\
\text { area }\end{array}$ & $\begin{array}{l}\text { Latitude } \\
\left({ }^{\circ} \mathrm{N}\right)\end{array}$ & Method & $\begin{array}{l}\text { Depth } \\
\text { (m) }\end{array}$ & $\begin{array}{c}\text { Temperature } \\
\left({ }^{\circ} \mathrm{C}\right)\end{array}$ & $\begin{array}{c}\text { Sample } \\
\text { no. }\end{array}$ \\
\hline 04/06/2005 & Okinoerabu Is. & 27.40 & Manned sub & $250-270$ & 16 & 3 \\
\hline 06/06/2005 & Iou Is. & 30.80 & Manned sub & $125-140$ & $14-15$ & 4 \\
\hline 08/06/2005 & Iou Is. & 30.80 & Manned sub & 138 & 15 & 1 \\
\hline $12 / 06 / 2005$ & Kikai Is. & 28.20 & Manned sub & 195 & 19 & 1 \\
\hline $13 / 06 / 2005$ & Kikai Is. & 28.20 & Manned sub & $212-215$ & 19 & 1 \\
\hline $18 / 06 / 2005$ & Iou Is. & 30.80 & Manned sub & $120-130$ & $17-18$ & 3 \\
\hline $19 / 06 / 2005$ & Take Is. & 30.80 & Manned sub & 130 & 17 & 1 \\
\hline $20 / 06 / 2005$ & Iou Is. & 30.80 & Manned sub & $145-160$ & $16-17$ & 2 \\
\hline $15 / 08 / 2005$ & Kita Chohozone & 25.30 & ROV & $312-316$ & 17 & 2 \\
\hline $18 / 08 / 2005$ & Yaebise & 25.00 & ROV & 239 & 19 & 1 \\
\hline $19 / 08 / 2005$ & Minna Is. & 24.75 & ROV & 315 & 17 & 1 \\
\hline $21 / 08 / 2005$ & Tarama Is. & 24.60 & ROV & 282 & 17 & 1 \\
\hline $24 / 08 / 2005$ & Ishigaki Is. & 24.40 & ROV & 290 & 16 & 1 \\
\hline $28 / 08 / 2005$ & Ishigaki Is. & 24.40 & ROV & 272 & 16 & 2 \\
\hline $29 / 08 / 2005$ & Hatoma Is. & 25.00 & ROV & 219 & 17 & 1 \\
\hline 20/09/2005 & Izena Is. & 27.00 & ROV & 202 & 20 & 1 \\
\hline $26 / 11 / 2005$ & Ishigaki Is. & 24.40 & ROV & 290 & 16 & 1 \\
\hline $28 / 11 / 2005$ & Tarama Is. & 24.60 & ROV & $205-232$ & 18 & 4 \\
\hline $19 / 12 / 2005$ & Izena Is. & 27.00 & ROV & $200-206$ & $17-20$ & 12 \\
\hline $20 / 12 / 2005$ & Izena Is. & 27.00 & ROV & $201-214$ & $19-20$ & 10 \\
\hline $23 / 12 / 2005$ & Ishigaki Is. & 24.40 & ROV & 303 & 17 & 1 \\
\hline $26 / 12 / 2005$ & Tanega Is. & 30.50 & Manned sub & $160-175$ & 17 & 2 \\
\hline $09 / 01 / 2006$ & Izena Is. & 27.00 & ROV & $194-197$ & $20-21$ & 3 \\
\hline $10 / 01 / 2006$ & Izena Is. & 27.00 & ROV & $194-197$ & $20-21$ & 1 \\
\hline $11 / 01 / 2006$ & Okinawa Is. & 26.50 & ROV & $215-221$ & 19 & 2 \\
\hline $15 / 01 / 2006$ & Ishigaki Is. & 24.40 & ROV & 307 & 15 & 1 \\
\hline $19 / 01 / 2006$ & Tarama Is. & 24.60 & ROV & 278 & 17 & 1 \\
\hline $20 / 01 / 2006$ & Tarama Is. & 24.60 & ROV & 277 & 14 & 1 \\
\hline $10 / 02 / 2006$ & Tanega Is. & 30.50 & Manned sub & $190-200$ & 16 & 3 \\
\hline $11 / 02 / 2006$ & Tanega Is. & 30.50 & Manned sub & 150 & 17 & 1 \\
\hline $12 / 02 / 2006$ & Tanega Is. & 30.50 & Manned sub & 145 & 17 & 1 \\
\hline $13 / 02 / 2006$ & Tanega Is. & 30.50 & Manned sub & 220 & 17 & 2 \\
\hline $14 / 02 / 2006$ & Tanega Is. & 30.50 & Manned sub & $165-220$ & $16-17$ & 2 \\
\hline $21 / 02 / 2006$ & Mage Is. & 30.80 & Manned sub & $120-125$ & 18 & 2 \\
\hline $22 / 02 / 2006$ & Mage Is. & 30.80 & Manned sub & $130-135$ & 18 & 3 \\
\hline $25 / 02 / 2006$ & Iou Is. & 30.80 & Manned sub & 155 & 18 & 1 \\
\hline $27 / 02 / 2006$ & Iou Is. & 30.80 & Manned sub & $130-135$ & $16-18$ & 2 \\
\hline $27 / 02 / 2006$ & Kuchierabu Is. & 30.40 & Manned sub & 145 & 17 & 1 \\
\hline $23 / 06 / 2007$ & Ishigaki Is. & 24.40 & ROV & 319 & 16 & 1 \\
\hline 05/07/2007 & Ishigaki Is. & 24.40 & ROV & 317 & 15 & 1 \\
\hline $16 / 08 / 2007$ & Ishigaki Is. & 24.40 & ROV & 249 & 19 & 2 \\
\hline $22 / 08 / 2007$ & Yaku Is. & 30.30 & Manned sub & 170 & 17 & 2 \\
\hline $30 / 08 / 2007$ & Amami Is. & 28.30 & Manned sub & $295-300$ & 18 & 2 \\
\hline $02 / 09 / 2007$ & Nakanougan Is. & 24.20 & ROV & 219 & 18 & 1 \\
\hline $04 / 09 / 2007$ & Tanega Is. & 30.80 & Manned sub & 145 & 17 & 1 \\
\hline 05/09/2007 & Hateruma Is. & 24.00 & ROV & 296 & 16 & 1 \\
\hline 06/09/2007 & Kakeroma Is. & 28.10 & Manned sub & 250 & 20 & 1 \\
\hline 08/09/2007 & Kikai Is. & 28.20 & Manned sub & 195 & 22 & 1 \\
\hline $12 / 09 / 2007$ & Ishigaki Is. & 24.40 & ROV & 228 & 18 & 1 \\
\hline $21 / 09 / 2007$ & Iou Is. & 30.80 & Manned sub & 150 & 18 & 1 \\
\hline $23 / 09 / 2007$ & Takeshima Is. & 30.80 & Manned sub & 140 & 17 & 1 \\
\hline $22 / 10 / 2007$ & Tanega Is. & 30.50 & Manned sub & 205 & 17 & 2 \\
\hline $23 / 10 / 2007$ & Amami Is. & 28.30 & Manned sub & 260 & 17 & 1 \\
\hline $29 / 10 / 2007$ & Tokuno Is. & 27.80 & Manned sub & 285 & 17 & 1 \\
\hline $06 / 11 / 2007$ & Iou Is. & 26.70 & ROV & 209 & 18 & 1 \\
\hline 08/11/2007 & Yuse & 30.80 & Manned sub & 120 & 20 & 1 \\
\hline $13 / 11 / 2007$ & Iou Is. & 30.80 & Manned sub & 130 & 17 & 1 \\
\hline $02 / 12 / 2007$ & Tarama Is. & 24.60 & ROV & $203-216$ & 19 & 2 \\
\hline
\end{tabular}


Appendix 1. (continued)

\begin{tabular}{|c|c|c|c|c|c|c|}
\hline $\begin{array}{l}\text { Date } \\
\text { (dd/mm/yy) }\end{array}$ & $\begin{array}{l}\text { Sampling } \\
\text { area }\end{array}$ & $\begin{array}{l}\text { Latitude } \\
\left({ }^{\circ} \mathrm{N}\right)\end{array}$ & Method & $\begin{array}{l}\text { Depth } \\
\text { (m) }\end{array}$ & $\begin{array}{c}\text { Temperature } \\
\left({ }^{\circ} \mathrm{C}\right)\end{array}$ & $\begin{array}{c}\text { Sample } \\
\text { no. }\end{array}$ \\
\hline 05/12/2007 & Tanega Is. & 30.50 & Manned sub & 175 & 19 & 3 \\
\hline 09/12/2007 & Iou Is. & 30.80 & Manned sub & 135 & 19 & 1 \\
\hline $10 / 12 / 2007$ & Tarama Is. & 24.40 & ROV & $251-261$ & $19-20$ & 2 \\
\hline 11/12/2007 & Iou Is. & 30.80 & Manned sub & 135 & 19 & 1 \\
\hline 18/12/2007 & Iou Is. & 30.80 & Manned sub & 115 & 20 & 1 \\
\hline 06/01/2008 & Take Is. & 30.80 & Manned sub & 130 & 18 & 1 \\
\hline 06/01/2008 & Ie Is. & 26.70 & ROV & 261 & 17 & 1 \\
\hline 08/01/2008 & Yaku Is. & 30.30 & Manned sub & 205 & 15 & 1 \\
\hline 08/01/2008 & Okinawa Is. & 26.90 & ROV & 303 & 17 & 1 \\
\hline 9/01/2008 & Izena Is. & 27.00 & ROV & 230 & 18 & 1 \\
\hline 05/02/2008 & Take Is. & 30.80 & Manned sub & 120 & 17 & 1 \\
\hline 07/03/2008 & Tarama Is. & 24.60 & $\mathrm{ROV}$ & $210-214$ & 20 & 2 \\
\hline 07/03/2008 & Yaebise & 25.00 & ROV & 220 & 20 & 1 \\
\hline 09/03/2008 & Hateruma Is. & 24.00 & ROV & 298 & 18 & 1 \\
\hline $16 / 03 / 2008$ & Nakanougan Is. & 24.20 & ROV & $203-207$ & 19 & 2 \\
\hline $25 / 03 / 2008$ & Hateruma Is. & 24.00 & ROV & 297 & 17 & 1 \\
\hline 29/03/2008 & Hatoma Is. & 25.00 & ROV & 219 & 19 & 1 \\
\hline 04/04/2008 & Yaebise & 25.00 & ROV & 237 & 19 & 1 \\
\hline 05/04/2008 & housanzone & 25.30 & ROV & 228 & 20 & 1 \\
\hline $13 / 04 / 2008$ & Nakanougan Is. & 24.20 & ROV & 212 & 18 & 1 \\
\hline $14 / 04 / 2008$ & Nakanougan Is. & 24.20 & ROV & 232 & 18 & 1 \\
\hline 05/05/2008 & Nakanougan Is. & 24.20 & ROV & 213 & 19 & 1 \\
\hline $18 / 05 / 2008$ & Iou Is. & 30.80 & Manned sub & 130 & 16 & 2 \\
\hline $21 / 05 / 2008$ & Iou Is. & 30.80 & Manned sub & $145-150$ & 16 & 2 \\
\hline $22 / 05 / 2008$ & Ishigaki Is. & 24.40 & ROV & 248 & 20 & 1 \\
\hline $22 / 05 / 2008$ & Yaebise & 24.90 & ROV & $216-225$ & 21 & 2 \\
\hline $27 / 05 / 2008$ & Housanzone & 25.30 & ROV & 226 & 20 & 1 \\
\hline Total & & & & & & 143 \\
\hline
\end{tabular}

